\title{
HIV/AIDS knowledge, attitudes and beliefs among a group of Iraqis
}

A.H. Hayyawi, ${ }^{1}$ A.Y. Al-Marayaty, ${ }^{7}$ W.S. Salman ${ }^{7}$ and W. Hamed ${ }^{2}$

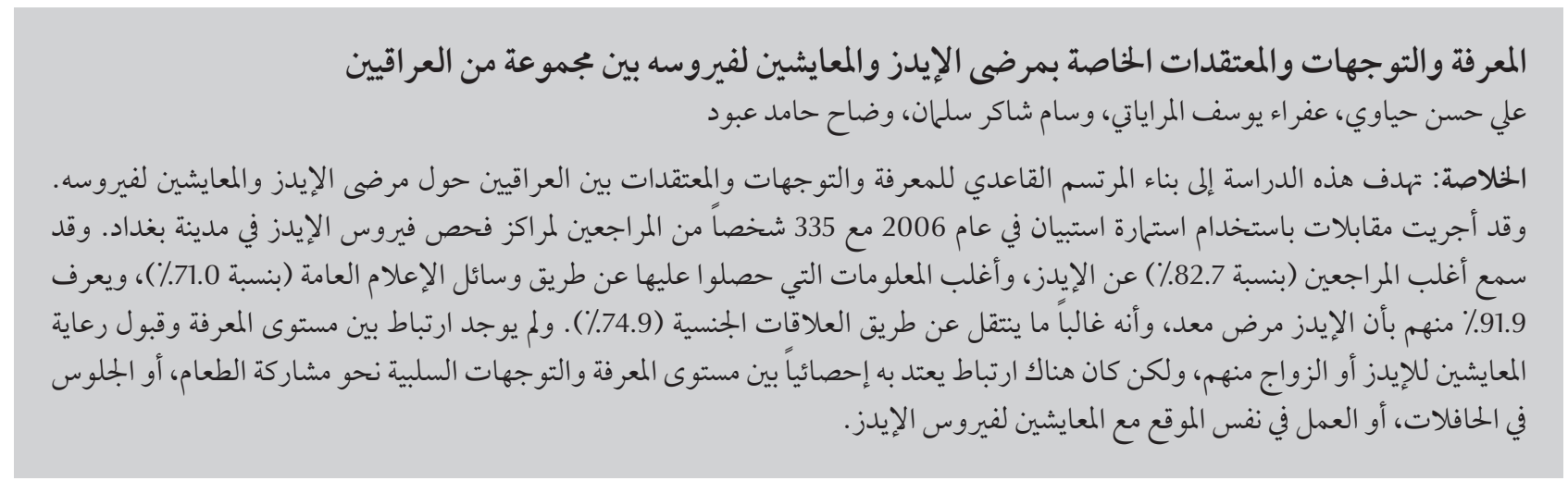

ABSTRACT This study aimed to build a baseline profile of knowledge, attitudes and beliefs of Iraqis toward HIV/AIDS. Questionnaire interviews were conducted in 2006 with 335 people attending HIV testing centres in Baghdad. Most respondents (82.7\%) had heard about AIDS, mainly from the mass media (71.0\%), and 91.9\% knew that AIDS is an infectious disease, most commonly via sexual relationships (74.9\%). There was no association between knowledge level and acceptance of caring for an HIV-positive relative or marrying an HIV-positive partner, but there was a significant association between low knowledge level and negative attitudes towards sharing food, sitting on the bus and working at the same place with an HIV-positive individual.

\section{Connaissances, attitudes et croyances en matière de $\mathrm{VIH} /$ sida dans un groupe d'Iraquiens}

RÉSUMÉ Cette étude visait à élaborer un profil de référence des connaissances, des attitudes et des croyances des Iraquiens concernant le VIH/sida. Des entretiens par questionnaire ont été réalisés en 2006 auprès de 335 personnes fréquentant des centres de dépistage du VIH à Bagdad. La plupart des personnes interrogées (82,7\%) avaient entendu parler du sida, principalement par le biais des médias $(71,0 \%)$, et 91,9\% d'entre elles savaient que le sida est une maladie infectieuse qui se transmet le plus souvent lors de relations sexuelles (74,9\%). Il n'existait pas d'association entre le niveau de connaissances et le fait d'accepter de s'occuper d'un membre de la famille séropositif ou de se marier avec une personne séropositive, mais il existait une association significative entre un faible niveau de connaissances et des attitudes négatives concernant le fait de partager la nourriture d'une personne séropositive, de s'asseoir dans un bus avec elle ou de travailler au même endroit qu'elle. 


\section{Introduction}

Acquired immunodeficiency syndrome (AIDS) is one of the most complex health problems of the 21 st century [1]. The AIDS epidemic is in its 3rd decade and has become a pandemic disease that threatens the world population [2]. Moreover, it continues to spread at an alarming rate [3]. Human immunodeficiency virus (HIV) is present in the blood and body fluids of infected individuals, whether symptomatic or asymptomatic. The main modes of transmission are sexual contact, exposure to infected blood or blood products and perinatal transmission [4].

In the absence of a vaccine or cure for HIV/AIDS, public health education is still the best means of combating the pandemic [5]. Public understanding of the virus is growing but many behavioural aspects of the epidemic remain incompletely documented and poorly understood. The impact of prevention programmes on behaviour remains uncertain because they frequently lack complementary information on changes in behaviour or because behavioural data are not collected or are incomplete [6].

Several studies conducted in countries in Asia and North Africa have evaluated HIV/AIDS knowledge, attitudes and practice of certain target populations such as university students $[3,5,7]$, army students [8], soldiers [9], street children/youth [10] and nurses [11]. Young people are particularly at risk of HIV infection because they are in the transition phase of their life, experimenting with sexual experiences and drug use [3]. The present study in Baghdad, Iraq covered a non-homogenous sector of the community (people attending HIV testing centres) and aimed to build a baseline profile of knowledge, attitudes and beliefs regarding HIV/AIDS among the study group. The study was also seen an opportunity to distribute correct information and to correct misconceptions about different aspects of HIV/AIDS among this group.

\section{Methods}

\section{Setting and sample}

A cross-sectional study was conducted in the Al-Risafa area of Baghdad. The area has 4 HIV testing centres that perform premarital counselling and testing, testing for Iraqis returning from other countries and voluntary counselling and testing. One centre also issues international health certificates on request.

A convenience sample of 335 subjects from both sexes attending the 4 HIV testing centres from April to June 2006 constituted the study group.

\section{Questionnaire}

A questionnaire was constructed to meet the purpose of the study based on similar studies of knowledge and attitudes in different countries $[1,3,12,13]$. The questions were modified according to Iraqi culture and social norms. The questionnaire included data related to personal information, knowledge and beliefs about HIV/AIDS, sources of knowledge, and attitudes toward HIV patients. The questionnaire was filled through a direct interview.

The possible responses to each question were yes, no or don't know, and items were scored as 2 (correct), 1 (don't know) or 0 (incorrect), with a maximum score of 17 . The median score (14) was calculated and the subjects were categorized into high knowledge level (> 14) and low knowledge level $(\leq 14)$ groups.

A pilot study was done on a sample of 25 individuals drawn from the same testing centres. According to their responses, some questions were modified to make them more applicable. The pilot sample was not included in the study.

\section{Ethical issues}

Written permission for the study was obtained from the appropriate local authority health manager. The questionnaire was administered to those who gave their verbal consent to participate. Participation was voluntary after explaining the purpose of the study to each individual. The questionnaire was anonymous and participants were assured of the confidentiality of their responses.

\section{Statistical analysis}

The data were analysed using SPSS, version 12 . The data were expressed as frequencies and percentages. The chisquared test was used and a $P$-value of $\leq$ 0.05 was considered as significant.

\section{Results}

A total of 335 respondents were included in the study: 196 (58.5\%) males and 139 (41.5\%) females. The mean age was 28 (standard deviation 9) years and $94.0 \%$ of the respondents were aged 44 years or less (Table 1).

Of the study group $79.1 \%$ were unmarried, $83.0 \%$ had secondary or higher education and $36.4 \%$ were employees. The proportion of respondents with high knowledge increased significantly with increasing educational status $(P<$ 0.001 ) (Table 2). There was no significant association between knowledge level and marital status $(P=0.16)$ but the association with occupation was significant $(P=0.021)$; employees had the greater knowledge than other occupation groups. Couples attending for premarital testing constituted $69.0 \%$ of the study group, followed by those attending for international health certificates (19.7\%) and people returning from travel abroad (11.3\%). Higher knowledge was significantly associated with attending for travel-related reasons compared with premarital testing $(P=$ 0.012) (Table 2). 
A high proportion of the study group $(277,82.7 \%)$ reported having heard about HIV/AIDS. Mass media was the main source of knowledge for 238 respondents $(71.0 \%)$, principally local television and satellite channels (49.3\%), followed by newspapers and magazines $(7.2 \%)$, folders/leaflets (3.6\%), radio broadcasts $(3.0 \%)$ or all of these (8.1\%). People were the second source of information $(145,43.3 \%)$, mainly medical staff (28.7\%), followed by friends $(7.5 \%)$, relatives $(6.3 \%)$ or all of these (0.9\%). Educational programmes were the lowest source of information (31, 9.3\%).

The majority of the study group $(308,91.9 \%)$ knew that AIDS was an infectious disease (Table 3). A high proportion (72.7\%) reported the possibility of transmission of the virus from the infected mother to her infant, while $11.5 \%$ denied this possibility while only

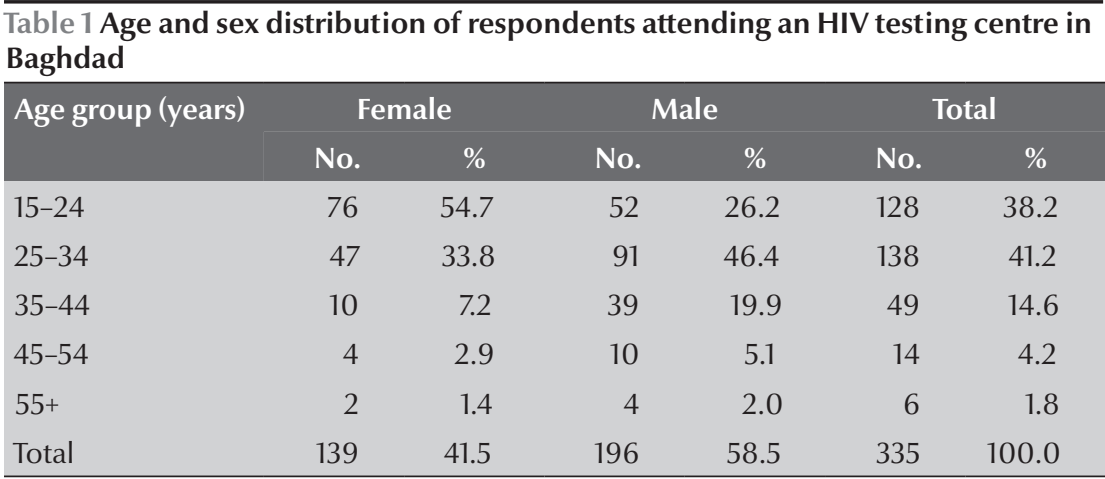

$37.5 \%$ reported the possibility of transmission of HIV through breastfeeding with $26.0 \%$ denying this as a method of transmission (Table 3). Just over half of the respondents (54.9\%) thought that AIDS was not a curable disease while $26.6 \%$ thought that it was curable and $18.5 \%$ did not know. Similar proportions had incorrect and correct knowledge about the existence of a vaccine (34.9\% and $39.4 \%$ respectively) and $25.7 \%$ admitted they did not know about the presence of a vaccine. A majority of the study group knew that sexual relationships were a method of transmission $(251,74.9 \%)$ and a high percentage gave a correct response about blood transfusion (71.6\%) and sharing syringes and sharp instruments (68.7\%) as methods of transmission. On the other hand, more than half of the sample believed incorrectly that HIV was transmitted by sharing food (56.7\%), shaking hands and social

\begin{tabular}{|c|c|c|c|c|c|c|c|}
\hline \multirow[t]{3}{*}{ Variable } & \multicolumn{6}{|c|}{ HIV/AIDS knowledge level } & \multirow[t]{3}{*}{ Statistical tests } \\
\hline & \multicolumn{2}{|c|}{ Low $(n=173)$} & \multicolumn{2}{|c|}{ High $(n=162)$} & \multicolumn{2}{|c|}{ Total $(n=335)$} & \\
\hline & No. & $\%$ & No. & $\%$ & No. & $\%$ & \\
\hline \multicolumn{8}{|l|}{ Marital status } \\
\hline Single & 144 & 83.2 & 121 & 74.7 & 265 & 79.1 & \multirow{3}{*}{$\chi^{2}=1.96, \mathrm{df}=1, P=0.16$} \\
\hline Married & 28 & 16.2 & 37 & 22.8 & 65 & 19.4 & \\
\hline Separated & 1 & 0.6 & 4 & 2.5 & 5 & 1.5 & \\
\hline \multicolumn{8}{|l|}{ Educational status } \\
\hline Illiterate & 10 & 5.8 & 1 & 0.6 & 11 & 3.3 & \multirow{4}{*}{$\chi^{2}=19.65, \mathrm{df}=3, P<0.001$} \\
\hline Primary & 29 & 16.8 & 17 & 10.5 & 46 & 13.7 & \\
\hline Secondary & 82 & 47.4 & 62 & 38.3 & 144 & 43.0 & \\
\hline Higher & 52 & 30.1 & 82 & 50.6 & 134 & 40.0 & \\
\hline \multicolumn{8}{|l|}{ Occupation } \\
\hline Housewife & 41 & 23.7 & 27 & 16.7 & 68 & 20.3 & \multirow{4}{*}{$\chi^{2}=9.72, \mathrm{df}=3, P=0.021$} \\
\hline Employee & 48 & 27.7 & 74 & 45.7 & 122 & 36.4 & \\
\hline Manual worker & 60 & 34.7 & 41 & 25.4 & 101 & 30.2 & \\
\hline Student & 24 & 13.9 & 20 & 12.3 & 44 & 13.1 & \\
\hline \multicolumn{8}{|l|}{ Reason for attendance } \\
\hline Premarital test & 131 & 56.7 & 100 & 43.3 & 231 & 69.0 & \multirow{3}{*}{$\chi^{2}=8.82, \mathrm{df}=2, P=0.012$} \\
\hline International health certificate & 24 & 36.4 & 42 & 63.6 & 66 & 19.7 & \\
\hline Back from travel & 18 & 47.3 & 20 & 52.7 & 38 & 11.3 & \\
\hline
\end{tabular}

$d f=$ degrees offreedom. 


\begin{tabular}{|c|c|c|c|c|c|c|}
\hline \multirow[t]{2}{*}{ Item } & \multicolumn{2}{|c|}{ Yes } & \multicolumn{2}{|c|}{ No } & \multicolumn{2}{|c|}{ Don't know } \\
\hline & No. & $\%$ & No. & $\%$ & No. & $\%$ \\
\hline AIDS is infectious & 308 & 91.9 & 27 & 8.1 & 0 & 0.0 \\
\hline Possible to transmit AIDS from mother-to-child & 249 & 72.7 & 34 & 11.5 & 52 & 15.8 \\
\hline Possible to transmit AIDS through breastfeeding & 125 & 37.5 & 89 & 26.0 & 121 & 36.5 \\
\hline AIDS is curable & 89 & 26.6 & 184 & 54.9 & 62 & 18.5 \\
\hline Vaccine against AIDS exists & 117 & 34.9 & 132 & 39.4 & 86 & 25.7 \\
\hline \multicolumn{7}{|l|}{ Modes of transmission of HIV } \\
\hline Sexual relationship & 251 & 74.9 & 84 & 25.1 & - & - \\
\hline Blood transfusion & 240 & 71.6 & 95 & 28.4 & - & - \\
\hline Sharing syringes \& sharp instruments & 230 & 68.7 & 105 & 31.3 & - & - \\
\hline Sharing food & 190 & 56.7 & 145 & 43.3 & - & - \\
\hline Shaking hands \& social relations & 188 & 56.1 & 147 & 43.9 & - & - \\
\hline Sharing bathroom \& toilet & 181 & 54.0 & 154 & 46.0 & - & - \\
\hline Insect bite & 169 & 50.4 & 166 & 49.6 & - & - \\
\hline
\end{tabular}

relationships (56.1\%), sharing a bathroom and toilet (54.0\%) and insect bites (50.4\%).

Table 4 shows the attitude of the individuals in the study group toward HIV-positive relatives and shows that there was no significant association between knowledge level and acceptance of caring for an HIV-positive relative $(P=0.11)$ or not changing marriage plans if the partner was found to be HIV positive $(P=0.53)$. However, respondents with a lower knowledge level were significantly more likely to have negative attitudes towards sharing food with an HIV-positive individual, sitting beside an HIV-positive individual in a bus or working with an HIV-positive individual in the same work place $(P=$ $0.003, P<0.001$ and $P<0.001$ respectively) (Table 4).

\section{Discussion}

The majority of the study group attending for HIV testing were in the reproductive age group, showing that the surveillance activities are properly targeting the at-risk group who are sexually active $[3,14,15]$.
In our study high educational level was associated with higher knowledge about AIDS, which agrees with the findings of a study in Turkey in 2005 [12], presumably as those with higher education can utilize written mass media channels that are not accessible to those with lower educational status. The significant association between non-manual occupation and knowledge level can be explained by the relationship that exists between occupation and educational status.

Mass media, especially the visual, is an accessible, widespread and effective means of knowledge dissemination. Local television and satellite channels represented the main source of information about HIV/AIDS in this study, while people, including medical staff, ranked second. The role of television channels should be emphasized in distributing accurate, active and effective messages to the population, especially the younger age groups, about sexually transmitted diseases. These messages should match our social norms and religious values. Our results agree with the findings of studies conducted in Bangladesh and Thailand $[16,17]$, but disagree with a study conducted in Saudi Arabia in which friends were the main source of information for males and booklets for females [13].

A majority of respondents gave correct responses about the methods of transmission of HIV, especially regarding sexual relationships, sharing of syringes and sharp instruments and blood transfusion. There were misconceptions about the risk from insect bites and routine daily activities, such as sharing food with HIV/AIDS patients or sharing toilets and bathrooms, which agrees with the findings of other studies $[13,18,19]$.

The majority of the study group accepted being a care provider for an HIV-positive relative, which can be explained by the strong family and social links in our society. The results of this study agree with those of a Ugandan study in 2000 which showed that $86.2 \%$ would provide care for relatives with HIV/AIDS [20], but disagrees with a study conducted in Kuwait during 1995 in which $72 \%$ were unwilling to take care of AIDS patients [21], and another study conducted in Sana'a, Yemen, which showed that only $21 \%$ thought that family members should provide care for HIV/AIDS patient and $51 \%$ thought that this care should be the responsibility of specialized staff in specialized centres [22]. 


\begin{tabular}{|c|c|c|c|c|c|c|c|}
\hline \multirow[t]{3}{*}{ Variable } & \multicolumn{6}{|c|}{ HIV/AIDS knowledge level } & \multirow[t]{3}{*}{ Statistical tests } \\
\hline & \multicolumn{2}{|c|}{$\operatorname{Low}(n=173)$} & \multicolumn{2}{|c|}{ High $(n=162)$} & \multicolumn{2}{|c|}{ Total $(n=335)$} & \\
\hline & No. & $\%$ & No. & $\%$ & No. & $\%$ & \\
\hline \multicolumn{8}{|l|}{ Agree to care for HIV-positive relative } \\
\hline Yes & 119 & 68.8 & 125 & 77.2 & 244 & 72.8 & \\
\hline No & 21 & 12.1 & 19 & 11.7 & 40 & 11.9 & $\chi^{2}=4.303, \mathrm{df}=2, P=0.116$ \\
\hline Don't know & 33 & 19.1 & 18 & 11.1 & 51 & 15.2 & \\
\hline \multicolumn{8}{|l|}{$\begin{array}{l}\text { Continue with marriage plan if partner } \\
\text { is found to be HIV positive }\end{array}$} \\
\hline Yes & 59 & 34.1 & 46 & 28.4 & 105 & 31.3 & \\
\hline No & 83 & 48.0 & 85 & 52.5 & 168 & 50.1 & $\chi^{2}=1.274, \mathrm{df}=2, P=0.529$ \\
\hline Don't know & 31 & 17.9 & 31 & 19.1 & 62 & 18.5 & \\
\hline \multicolumn{8}{|l|}{ Eating with an HIV-positive individual } \\
\hline Continue eating & 35 & 20.2 & 56 & 34.6 & 91 & 27.2 & \\
\hline Shift to other table & 35 & 20.2 & 38 & 23.5 & 73 & 21.8 & $\chi^{2}=11.79, \mathrm{df}=2, P=0.003$ \\
\hline Leave the place & 103 & 59.5 & 68 & 42.0 & 171 & 51.0 & \\
\hline \multicolumn{8}{|l|}{$\begin{array}{l}\text { Sitting beside an HIV-positive individual } \\
\text { in a bus }\end{array}$} \\
\hline Stay in place & 39 & 22.5 & 58 & 35.8 & 97 & 29.0 & \\
\hline Change place & 37 & 21.4 & 49 & 30.2 & 86 & 25.7 & $\chi^{2}=16.66, \mathrm{df}=2, P<0.001$ \\
\hline Leave the bus & 97 & 56.1 & 55 & 34.0 & 152 & 45.4 & \\
\hline \multicolumn{8}{|l|}{$\begin{array}{l}\text { Working with an HIV-positive } \\
\text { individual }\end{array}$} \\
\hline Stay in work & 36 & 20.8 & 59 & 36.4 & 95 & 28.4 & \\
\hline Ask to shift to another department & 71 & 41.0 & 66 & 40.7 & 137 & 40.9 & $\chi^{2}=13.57, \mathrm{df}=2, P<0.001$ \\
\hline Leave work & 66 & 38.2 & 37 & 22.8 & 103 & 30.7 & \\
\hline
\end{tabular}

$d f=$ degrees offreedom.

Over a quarter of the study group (26.6\%) thought that AIDS was a curable disease, which is close to the results of a Turkish study (30\%) conducted during 2005 [12]. More than one-third of the respondents (34.9\%) thought that there was a vaccine against the disease which is higher than the results of an Iranian study (11\%) conducted during 2004 [3]. These false beliefs reflect risky misconceptions which need to be corrected by effective educational information.

Respondents' knowledge level was associated with negative attitudes towards HIV-positive individuals in public places and at work, since the group with higher knowledge level were more accepting towards contact with HIVpositive individuals than those with low knowledge level. This agrees with the results of the Turkish study where people with good knowledge about AIDS were more tolerant of people with AIDS [12]. However, more than half of our study sample overall would avoid HIV-positive individuals at work or in public.

\section{Conclusion}

The sample in this study may not necessarily represent the population of Baghdad but it does represent an important subgroup of Baghdadis for evaluating knowledge and attitudes towards HIV/AIDS individuals. The study identified many misconceptions and negative attitudes that need to be addressed. A nationwide health education programme through mass media campaigns and introduction of HIV/AIDS education into the secondary school curriculum are recommended to overcomemisconceptions, spread awareness and, hopefully, modify behaviour.

\section{Acknowledgements}

The authors would like to greatly thank Professor Nada Al Ward for her kind efforts in the revision of the work. 


\section{References}

1. Tumer A, Unal S. Epidemiology of HIV infection in the world and Turkey. In: Unal S, ed. AIDS: modern medical seminars. Ankara, Turkey, Gunes Publishers, 2000:1-10.

2. AIDS epidemic update 2003. Geneva, Joint United Nations Programme on HIV/AIDS/World Health Organization, 2003.

3. Tavoosi A et al. Knowledge and attitude towards HIV/AIDS among Iranian students. BMC public health, 2004, 4:17.

4. Guidelines for HIV infection control: technical review. Baghdad, Iraq, Ministry of Health AIDS Research Centre and Cairo, World Health Organization Regional Office for the Eastern Mediterranean, 2005.

5. Farhan SF. Knowledge and attitude of undergraduate medical and non-medical students towards acquired immuno-deficiency syndrome (AIDS) [Fellowship thesis]. Baghdad, Iraq, Scientific Counsel of Family Medicine, Iraqi Board for Medical Specialization in Community Medicine, 2006.

6. Pisani E et al. Meeting the behavioural data collection needs of national HIV/AIDS and STD programmes. A joint IMPACT / FHI / UNAIDS workshop: report and conclusions. Geneva, Switzerland, Joint United Nations Programme on HIV/AIDS, 1998.

7. Ungan M, Yaman H. AIDS knowledge and educational needs of technical university students in Turkey. Patient education and counselling, 2003, 51:163-7.

8. Kilic $S$ et al. Sağlik astsubay meslek yüksek okulu öğrencilerinin HIV/AIDS hakkindaki bilgi düzeyleri ve tutumlari [Knowledge level and attitude of health non-commissioned officer students about HIV/AIDS.] TSK koruyucu hekimlik bulteni, 2004, 3:111-118.

9. Bakir B et al. Approaches of a group of solders in Istanbul and Ankara about AIDS. Gulhane medical journal, 2003, 45:19-24.

10. Baybuga MS, Celik SS. The level of knowledge and views of the street children/youth about AIDS in Turkey. International journal of nursing studies, 2004, 41:591-7.

11. Tebourski F, Ben Alaya D. Knowledge and attitudes of high school students regarding HIV/AIDS in Tunisia. Does more knowledge lead to more positive attitudes? Journal of adolescent health, 2004, 34:161-4.

12. Ayranci U. AIDS knowledge and attitudes in a Turkish population: an epidemiological study. BMC public health, 2005, 5:95.

13. Al-Mazrou YY, Abouzeid MS, Al-Jeffri MH. Knowledge and attitudes of paramedical students in Saudi Arabia toward HIV/ AIDS. Saudi medical journal, 2005, 26(8):1183-9.

14. 2004 Report on the global AIDS epidemic. Geneva, Joint United Nations Programme on HIV/AIDS, 2004.

15. Fowler MG, Melnick SL, Mathieson BJ. Women and HIV. Epidemiology and global overview. Obstetrics and gynecology clinics of North America, 1997, 24:705-29.

16. Unsal A et al. Level of knowledge of nurses about AIDS in several health services in Eskisehir. General medical journal, 1999, 9:53-8.

17. Irving KL et al. Nurses' evaluations of sources of information about HIV and AIDS. Journal of the Royal Society of Health, 1997, 117:298-303.

18. Carducci A et al. AIDS: Related information, attitude and behaviours among Italian male young people. European journal of epidemiology, 1995, 11:23-31.

19. Sikland A, Fisher M, Friedman S. AIDS knowledge, concerns and behavioural changes among inner-city high school students. Journal of adolescent health, 1996, 18:325-8.

20. Okware $S$ et al. Fighting HIV/AIDS: is success possible? Bulletin of the World Health Organization, 2001, 79(12):1113-20.

21. Al-Jabri A, Al-Abri JH. Knowledge and attitudes of undergraduate medical and non-medical students in Sultan Qaboos University toward acquired immune deficiency syndrome. Saudi medical journal, 2003, 24(3):273-7.

22. Al-Owaish RA et al. Knowledge, attitude, beliefs and practices of the population in Kuwait about AIDS-a pilot study. Eastern Mediterranean health journal, 1995, 1(2):235-40.

\section{Note from the Editor}

We wish to draw the kind attention of our potential authors to the importance of applying the editorial requirements of EMHJ when preparing their manuscripts for submission for publication. These provisions can be seen in the Guidelines for Authors, which are available online at http:/ / www.emro.who.int/emhj.htm, and are published at the end of the first issue of each volume. We regret that we are unable to consider papers that do not conform to the Guidelines. 